\title{
Genital yeasts in female patients attending a VD clinic
}

\author{
F. E. WILLMOTT \\ Leicester Royal Infirmary \\ 'Candida here, Candida there, Candida everywhere' G. B. SHAW
}

Recent reports have indicated an increase in the incidence of yeast infections in venereal disease clinics (Catterall, 1971; Oriel, Partridge, Denny, and Coleman, 1972). The widespread use of antibiotics, oral contraceptives, steroids, and immunosuppressive drugs have all contributed to this ascendancy; even the change of women's fashion to the wearing of tights has been implicated (Bull, 1972).

The present study was undertaken to find the frequency of yeast infections and assess the role of some of the factors mentioned above in patients attending a venereal disease clinic.

\section{Method}

552 patients attending as new cases at the Leicester Royal Infirmary between January and December, 1973, were the subjects of the study (this represented approximately $\frac{1}{3}$ of new female patients seen during this period).

A history was taken with special reference to the use of oral contraceptives and antibiotics during the previous 3 months. The patients were then examined and the following tests performed:

(1) Urethral and cervical smears were Gram-stained and examined under oil immersion for the presence of gonococci.

(2) Swabs were taken from the cervix and cultured on Oxoid G.C. selective medium for N. gonorrhoeae.

(3) Cervical swabs were also sent for viral culture in a transport medium consisting of a balanced salt solution (Hanks's) with 10 per cent. sorbitol, 10 per cent. heatinactivated calf serum, 0.22 per cent. bicarbonate, and an antibiotic.

(4) Wet vaginal smears were examined under light microscopy for yeasts and trichomonads.

(5) Vaginal smears were Gram-stained and examined for yeasts.

(6) Vaginal swabs were plated onto Oxoid Sabouraud's medium and put into Oxoid Trichomonas No. 2 medium for culture of yeasts and Trichomonas vaginalis.

Received for publication August 2, 1974

Address for reprints: F. E. Willmott, Leicestershire Area Health Authority ( $T$ ), Leicester Royal Infirmary, Leicester LE1 5WW
Positive yeast cultures were examined by the germ-tube method to identify Candida albicans (using the technique advised by Dolan and Ihrke, 1971). Laboratory facilities were not available for identification of Candida species other than albicans and they were grouped collectively as 'Other Yeasts'.

\section{Findings}

Yeast were isolated from 207 of the 552 patients ( 37.5 per cent.). 154 were further classified into C. albicans and 'Other Yeasts'. C. albicans accounted for 132 (86 per cent. of the 154.)

\section{AGE INCIDENCE (Fig. 1)}

There are no statistically significant differences in the incidences in the various age groups under the age of 40 years.
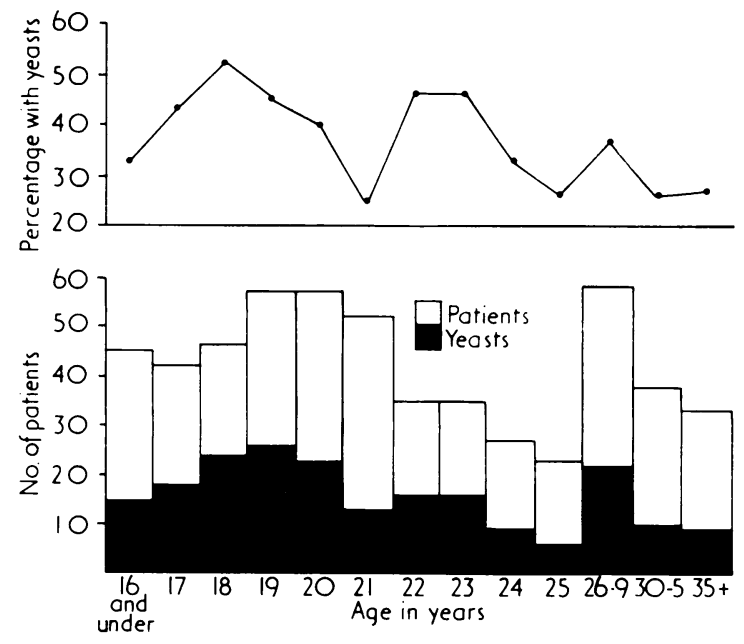

FIG. 1 Age incidence 
SEASONAL INCIDENCE (Fig. 2)

There is no seasonal variation. The apparent increase in January is not statistically significant $(P=0 \cdot 8)$.
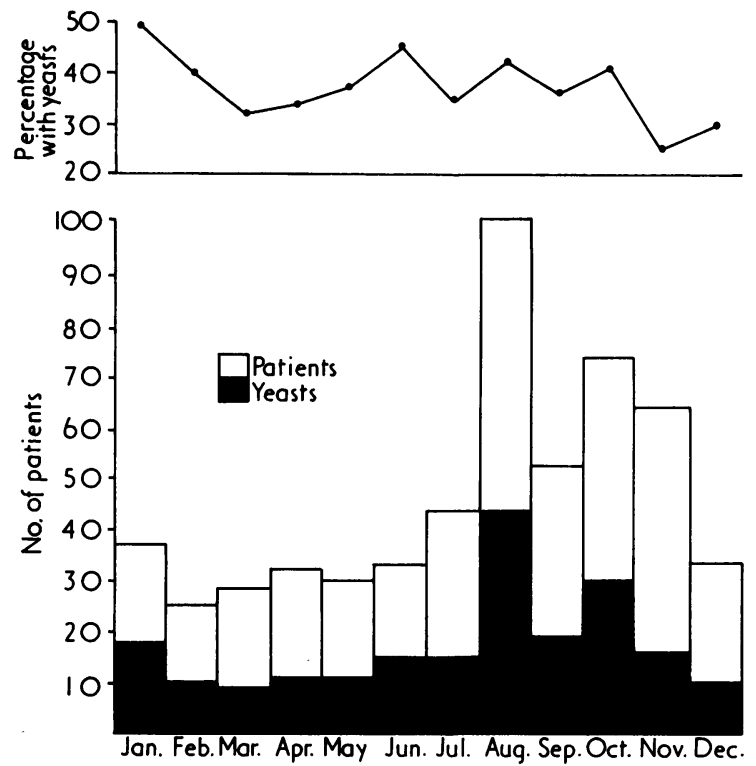

FIG. 2 Seasonal incidence

EFFECT OF ORAL CONTRACEPTIVES ('the pill')

The number of patients on 'the pill' was 236 of the 552 (42.8 per cent.). The incidence of yeasts was 102 out of $236(43.2$ per cent) among those on 'the pill' and 105 out of 316 (33.2 per cent.) not on 'the pill'. This is just statistically significant $(P=0.05)$. See Table I.

TABLE I Oral contraceptives and yeast isolation

\begin{tabular}{|c|c|c|c|}
\hline \multirow[t]{2}{*}{$\begin{array}{l}\text { Oral } \\
\text { contraceptives }\end{array}$} & \multirow[t]{2}{*}{$\begin{array}{l}\text { No. of } \\
\text { patients }\end{array}$} & \multicolumn{2}{|c|}{$\begin{array}{l}\text { Yeast } \\
\text { isolations }\end{array}$} \\
\hline & & No. & Per cent \\
\hline Taken & 236 & 102 & $43 \cdot 2$ \\
\hline Not taken & 316 & 105 & $33 \cdot 2$ \\
\hline Total & 552 & 207 & 37.5 \\
\hline
\end{tabular}

EFFECT OF PREVIOUS MEDICATION (Table II)

Patients who had had antibiotics, metronidazole, or steroids in the previous 3 months were included.
TABLE II Effect of previous antibiotics, metronidazole, or steroids

\begin{tabular}{|c|c|c|c|}
\hline \multirow[t]{2}{*}{ Findings } & $\begin{array}{l}\text { No. of } \\
\text { patients }\end{array}$ & $\begin{array}{l}\text { Previous antibiotics, } \\
\text { metronidazole, or steroids }\end{array}$ & \\
\hline & & No. & Per cent. \\
\hline Yeasts & 207 & 48 & $23 \cdot 2$ \\
\hline No yeasts & 345 & 47 & $13 \cdot 6$ \\
\hline Total & 552 & 95 & $17 \cdot 2$ \\
\hline
\end{tabular}

These totalled 95, of whom twelve had taken metronidazole and one a steroid. The number was 48 of 207 ( 23.2 per cent.) among those who had yeasts and 47 of 345 (13.6 per cent.) among those without yeasts $(P<0.01)$. In the 207 with yeasts, 25 had had previous antibiotics or metronidazole for vaginal discharge or 'cystitis' (symptoms which could be related to a yeast infection) compared with 20 of the 345 without yeasts $(P<0.02)$. Among the 95 patients who had had the above drugs, $48(50.5$ per cent) had yeasts compared with 159 of the 457 (35 per cent.) who had not taken them $(P<0.01)$.

\section{ASSOCIATED INFECTIONS (Table III)}

An interesting finding is the higher incidence of Trichomonas in patients not on 'the pill'. Even if we exclude patients who had previously had metronidazole, the incidence of Trichomonas is 16 out of 228 in those on 'the pill' and 61 out of 312 in those not on 'the pill' $(P<0.01)$. This suggests that 'the pill' produces an environment less suitable for the Trichomonas.

\section{DIAGNOSIS}

The diagnosis of yeast infection was made by examination of a stained smear or culture. The number positive on smear was $74(35.7$ per cent.) and on culture alone 133 (64.3 per cent.). Culture is thus the most sensitive method (Table IV).

The majority of yeast infections were not diagnosed at the initial attendance. Some of these patients were treated with antibiotics and/or metronidazole for other infections. Table $\mathrm{V}$ shows that only a few of these were found to have developed symptoms or to be positive on smear at a second examination.

TABLE II I Associated infections and use of contraceptive pill

\begin{tabular}{|c|c|c|c|c|}
\hline \multirow[b]{2}{*}{ Associated infections } & \multicolumn{2}{|l|}{ Pill (236) } & \multicolumn{2}{|l|}{ No pill (316) } \\
\hline & Yeasts (102) & No yeasts (134) & Yeasts (105) & No yeasts (211) \\
\hline Trichomonas & 5 ( 5 per cent.) & 11 (8 per cent.) & 19 (18 per cent.) & 42 (20 per cent.) \\
\hline Gonorrhoea & 14 (14 per cent.) & 22 (16 per cent.) & 15 (14 per cent.) & 48 (23 per cent.) \\
\hline Herpes simple $x^{a}$ & $5: 60$ & $3: 94$ & $1: 74$ & $5: 134$ \\
\hline
\end{tabular}

${ }^{\mathrm{a}}$ Viral cultures were done on 362 patients as part of another study 
TABLE IV Comparison of culture and smear results

\begin{tabular}{|c|c|c|}
\hline \multirow[b]{2}{*}{ Culture } & \multicolumn{2}{|l|}{ Smear } \\
\hline & Positive & Negative \\
\hline Positive & 73 & 133 \\
\hline Negative & 1 & 345 \\
\hline
\end{tabular}

TABLE V Effect of antibiotics or metronidazole on asymptomatic yeast infections

\begin{tabular}{lll}
\hline No. treated & $\begin{array}{l}\text { Smear positive or } \\
\text { symptoms on return }\end{array}$ \\
\cline { 2 - 3 } & No. & $\frac{\text { Per cent. }}{18.5}$ \\
\hline 27 & 5 & 18.5 \\
\hline
\end{tabular}

\section{SIGNS AND SYMPTOMS}

The symptoms of yeast infection may be pruritus, dysuria, dyspareunia (these are included in Table VI under the general term of irritation), or discharge. The frequency of these symptoms was the same whether or not the patients were on 'the pill' (Table VI). Thus about 30 per cent of women with yeasts were symptom free.

TABLE VI Symptoms and the presence of yeast infection, related to use of oral contraceptive

\begin{tabular}{|c|c|c|c|}
\hline \multirow[b]{2}{*}{ Pill } & \multicolumn{3}{|l|}{ Symptoms } \\
\hline & Total & Irritation & Discharge \\
\hline $\begin{array}{l}\text { Yes } \\
(102)\end{array}$ & 72 (70 per cent.) & 51 (50 per cent.) & 38 ( 37 per cent.) \\
\hline $\begin{array}{l}\text { No } \\
(105)\end{array}$ & 74 (70 per cent.) & 58 (55 per cent.) & 39 (37 per cent.) \\
\hline
\end{tabular}

Typical candidal vaginitis (creamy white discharge with plaques on the vaginal walls) was present in only 21 cases ( 10 per cent.). About 30 per cent. had a degree of vulvitis or vaginitis. The majority showed no signs related to the presence of yeasts.

OTHER YEASTS (Table VII)

'Other Yeasts' were isolated in 22 out of 154 (14.3 per cent.).

TABLE VII 'Other yeasts' in 154 cases further investigated, related to use of oral contraceptive

\begin{tabular}{|c|c|c|c|c|}
\hline \multicolumn{2}{|l|}{ Pill } & \multirow{2}{*}{$\frac{Y e s}{13}$} & \multirow{2}{*}{$\frac{N o}{9}$} & \multirow{2}{*}{$\frac{\text { Total }}{22(14 \text { per cent. })}$} \\
\hline Other yeasts & Positive & & & \\
\hline & Symptoms & 8 & 4 & 12 (55 per cent.) \\
\hline & Smear positive & 4 & 3 & 7 (32 per cent.) \\
\hline & Culture only & 9 & 6 & 15 (68 per cent. $)$ \\
\hline
\end{tabular}

\section{Consorts}

93 male consorts of women with yeasts were seen, and yeasts were found to be present in 31 (33 per cent.); the diagnosis was by stained smears and/or culture, mostly of subpreputial material. Cultures were taken in 47 of the men and 23 (49 per cent.) were positive. Only two of these 23 men were circumcised. C. albicans was identified in 20 (87 per cent.) of the 23 . The female consorts of nine (29 per cent.) had no symptoms.

\section{Discussion}

The findings in this survey must be considered with respect to the type of patient. This is a selected group, who by the nature of the clinic, are likely to be in the younger age group and more sexually active than the average populace. The high incidence may be related to this and also to the presence of other genital infections (or previous episodes of infection). However, an incidence of 37.5 per cent. is high compared with other studies in a similar group (Oriel and others, 1972-26 per cent.; Rohatiner and Grimble, 197019 per cent.) and higher than in general practice (Anyon, Desmond, and Eastcott, 1971-19 per cent.).

The occurrence of Candida (this term is now used rather than yeast because the discussion on pathogenicity which follows may not hold for species other than Candida) appears to depend on many factors. Oral contraceptives predispose to infection ( $\mathcal{F}$. Amer. med. Ass., 1966; Walsh, Hildebrandt, and Prystowsky, 1968; Catterall, 1971), although in this series the effect is not so marked. The effect of previous antibiotics is also a known factor (Torack, 1957) and this is shown in the present study.

More important than incidence is pathogenicity and its assessment. Candida is present in some patients in apparently a saprophytic role (30 per cent. in this series). Drake and Maibach (1973) suggested that the only reliable way to establish pathogenicity is to see the mycelial and yeast forms in the diseased material. In this series only 35.7 per cent. were positive on smear, yet of the 133 patients positive only on culture 83 ( 62 per cent.) had symptoms relieved by treatment. Also, 10 per cent. of male consorts had mycotic infection from women with no symptoms and positive only on culture. The change from saprophyte to pathogen has been related to the taking of antibiotics, but only five out of 27 developed signs or symptoms after antibiotics even though Candida was known to be present.

The clinical problem is whether to treat these asymptomatic cases. Oriel and others (1972) have advocated treating all such cases. In general, even saprophytic yeasts are potential pathogens not only to the carrier but also to possible consorts. It is probably wiser to consider each of these cases individually rather than make a general rule.

In some cases sexual transmission will be a factor (Teokharov, 1969). One-third of consorts seen had evidence of yeast infection and where cultures were taken almost half were positive. Treatment of 
the consort should therefore be undertaken as suggested by Drake and Maibach (1973).

\section{Summary}

A study of 552 female patients was undertaken to determine the frequency of yeast infections in women attending a V.D. clinic. The findings were as follows:

(1) 207 of the 552 (37.5 per cent.) were found to have yeasts.

(2) C. albicans accounted for 86 per cent. of these yeasts.

(3) There was no difference in incidence related to age or seasonal variation.

(4) Oral contraceptives increased the incidence of yeasts (43.2 per cent. on 'the pill'; 33.2 per cent. not on 'the pill'), but the incidence of Trichomonas was decreased ( 6.8 per cent. on 'the pill', 19.3 per cent. not on 'the pill').

(5) Previous antibiotics also contributed to the incidence; 23.2 per cent. of patients with yeasts had had antibiotics previously compared with 13.6 per cent. of those without yeasts.

(6) Other infections were associated in seventy cases (33.8 per cent.).

(7) Culture is essential for the detection of yeasts; 64 per cent. were positive only on culture.

(8) Symptoms were present in 70 per cent. of patients with yeasts.

(9) 93 male consorts were seen and in 31 (33 per cent.) yeasts were detected by smear, or culture. Of the 47 in whom cultures were examined, 23 (49 per cent.) were positive.

The general factors affecting the incidence of yeasts are discussed as well as the differentiation of the saprophytic from the pathogenic role of yeasts. It is suggested that asymptomatic yeast infections are often best treated, but that each case should be considered individually. Male consorts should also be treated to prevent re-infection.

I wish to express my appreciation to Dr. Helene J. Mair for the viral cultures performed at the Public Health Laboratories, Groby Road, Leicester.

\section{References}

Anyon, C. P., Desmond, F. B., and Eastcott, D. F. (1971) N.Z. med.F., 73, 9

BuLL, M. J. V. (1969) Brit. med. F., 1, 120

CATTERALl, R. D. (1971) Brit. F. vener. Dis., 47, 45

Drake, T. E., and MaIBaCh, H. I. (1973) Postgrad. Med., 53, No. 2, p.83; No. 3, p.120
Dolan, C. T., and IHRKE, D. M. (1971) Amer. F. clin. Path., 55,733

F. Amer. med. Ass. (1966) 196, 731 (Editorial)

Oriel, J. D., Partridge, B. M., Denny, M. J., and Colmman, J. C. (1972) Brit. med. f., 4, 761

Rohatiner, J. J., and Grimble, A. (1970) f. Obstet. Gynaec. Brit. Cwlth, 77, 1013

Teokharov, B. A. (1969) Brit. F. vener. Dis., 45, 334

TORACK, R. M. (1957) Amer. F. Med., 22, 872

Walsh, H., Hildebrandt, R. J., and PRYstowsky, H. (1968) Amer. F. Obstet. Gynec., 93, 904

Levures génitales chez les consultantes d'une clinique vénérologique

\section{SOMMAIRE}

On entreprit une étude sur 552 femmes pour apprécier la fréquence des infections à levures chez les consultantes d'une clinique vénérologique. Les résultats furent les suivants:

(1) Des levures furent trouvées chez 207 de ces 552 femmes (37,5 pour cent).

(2) Le C. albicans fut en compte pour 86 pour cent de ces levures.

(3) Il ne fut pas trouvé de différence d'incidence selon l'âge ou les variations saisonnières.

(4) La prise de contraceptifs oraux augmenta l'incidence des levures: (43,2 pour cent prenaient la pilule; 33,2 pour cent ne la prenaient pas) mais l'incidence de la trichomonase fut diminuée $(6,8$ pour cent prenaient la pilule; 19,3 pour cent ne la prenaient pas).

(5) L'incidence fut également notée après prise d'antibiotiques; 23,2 pour cent des malades présentant des levures avaient reçu des antibiotiques antérieurement contre 13,6 pour cent pour celles qui n'avaient pas de levures.

(6) D'autres infections furent associées dans 70 cas (33,8 pour cent).

(7) La culture est essentielle pour la détection des levures; 64 pour cent de cas furent positifs seulement pour la culture.

(8) Des symptômes existaient chez 70 pour cent des malades présentant des levures.

(9) 93 partenaires masculins furent examinés, et chez 31 (33 pour cent) des levures furent trouvées sur lames ou par culture. Sur les 47 pour lesquels des cultures furent examinées, 23 ( 49 pour cent) furent positifs.

On discute des facteurs généraux touchant à l'incidence des levures, aussi bien que la différenciation du rôle des saprophytes et des levures pathogènes. Il est suggéré que les infections à levures asymptomatiques sont souvent les mieux traitées mais que chaque cas doit être considéré individuellement. Les partenaires masculins doivent être également traités pour prévenir les réinfections. 